\title{
Front Matter: Volume 10360
}

, "Front Matter: Volume 10360," Proc. SPIE 10360, Light Manipulating Organic Materials and Devices IV, 1036001 (24 October 2017); doi: 10.1117/12.2296915

SPIE Event: SPIE Organic Photonics + Electronics, 2017, San Diego, California, SPIE. United States 


\title{
PROCEEDINGS OF SPIE
}

\section{Light Manipulating Organic Materials and Devices IV}

\author{
Manfred Eich \\ Jean-Michel Nunzi \\ Jon A. Schuller \\ Joy E. Haley \\ Editors
}

6-7 August 2017

San Diego, California, United States

Sponsored by

SPIE

Cosponsored by

Kolon Industries, Inc. (Korea, Republic of)

Published by

SPIE 
The papers in this volume were part of the technical conference cited on the cover and title page. Papers were selected and subject to review by the editors and conference program committee. Some conference presentations may not be available for publication. Additional papers and presentation recordings may be available online in the SPIE Digital Library at SPIEDigitalLibrary.org.

The papers reflect the work and thoughts of the authors and are published herein as submitted. The publisher is not responsible for the validity of the information or for any outcomes resulting from reliance thereon.

Please use the following format to cite material from these proceedings:

Author(s), "Title of Paper," in Light Manipulating Organic Materials and Devices IV, edited by Manfred Eich, Jean-Michel Nunzi, Jon A. Schuller, Joy E. Haley, Proceedings of SPIE Vol. 10360 (SPIE, Bellingham, WA, 2017) Seven-digit Article CID Number.

ISSN: 0277-786X

ISSN: 1996-756X (electronic)

ISBN: 9781510611771

ISBN: 9781510611788 (electronic)

Published by

SPIE

P.O. Box 10, Bellingham, Washington $98227-0010$ USA

Telephone +1 3606763290 (Pacific Time) · Fax +1 3606471445

SPIE.org

Copyright (C) 2017, Society of Photo-Optical Instrumentation Engineers.

Copying of material in this book for internal or personal use, or for the internal or personal use of specific clients, beyond the fair use provisions granted by the U.S. Copyright Law is authorized by SPIE subject to payment of copying fees. The Transactional Reporting Service base fee for this volume is $\$ 18.00$ per article (or portion thereof), which should be paid directly to the Copyright Clearance Center (CCC), 222 Rosewood Drive, Danvers, MA 01923. Payment may also be made electronically through CCC Online at copyright.com. Other copying for republication, resale, advertising or promotion, or any form of systematic or multiple reproduction of any material in this book is prohibited except with permission in writing from the publisher. The CCC fee code is $0277-$ $786 \mathrm{X} / 17 / \$ 18.00$

Printed in the United States of America.

Publication of record for individual papers is online in the SPIE Digital Library.

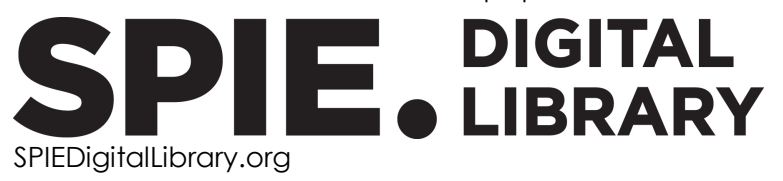

Paper Numbering: Proceedings of SPIE follow an e-First publication model. A unique citation identifier (CID) number is assigned to each article at the time of publication. Utilization of CIDs allows articles to be fully citable as soon as they are published online, and connects the same identifier to all online and print versions of the publication. SPIE uses a seven-digit CID article numbering system structured as follows:

- The first five digits correspond to the SPIE volume number.

- The last two digits indicate publication order within the volume using a Base 36 numbering system employing both numerals and letters. These two-number sets start with $00,01,02,03$, 04, 05, 06, 07, 08, 09, OA, OB ... 0Z, followed by 10-1Z, 20-2Z, etc. The CID Number appears on each page of the manuscript. 


\title{
Contents
}

\author{
$\checkmark \quad$ Authors \\ vii Conference Committee
}

\section{SESSION 1 NONLINEAR OPTICAL PROCESSES AND MECHANISMS I}

1036003 Light-induced "plasmonic" properties of organic materials: surface polaritons, bistability and switching waves (Invited Paper) [10360-1]

1036004 Reverse saturable absorption (RSA) in fluorinated iridium derivatives [10360-2]

SESSION 2 NONLINEAR OPTICAL PROCESSES AND MECHANISMS II

1036007 Dynamic amplification of light signals in photorefractive ferroelectric liquid crystal blends containing photoconductive chiral dopant (Invited Paper) [10360-5]

10360 OA Enhanced nonlinear optical limiting in TiS 2 dichalcogenide 2D sheets (Invited Paper) [10360-8]

\section{POSTER SESSION}

$10360 \mathrm{OL}$ The study of polyelectrolyte-containing photoanisotropic compositions [10360-20] 
Proc. of SPIE Vol. $103601036001-4$ Downloaded From: https://www.spiedigitallibrary.org/conference-proceedings-of-spie on 26 Apr 2023
Terms of Use: https://www.spiedigitallibrary.org/terms-of-use 


\section{Authors}

Numbers in the index correspond to the last two digits of the seven-digit citation identifier (CID) article numbering system used in Proceedings of SPIE. The first five digits reflect the volume number. Base 36 numbering is employed for the last two digits and indicates the order of articles within the volume. Numbers start with 00, 01, 02, 03, 04, 05, 06, 07, 08, 09, OA, OB...0Z, followed by 10-1Z, 20-2Z, etc.

Ajayan, Pulickel M., OA

Aliyan, Amir, OA

Apter, Boris, 03

Bambha, Neal, 04

Chaganava, Irakli, OL

Ensley, Trenton R., 04

Fainberg, Boris D., 03

Ferry, Michael J., 04

Funada, K., 07

Hafuri, M., 07

Kakauridze, George, OL Kilosanidze, Barbara, OL

Kobulashvili, Irine, OL

Kumar, Jitesh, OA

Layne, Katherine, $\mathrm{OA}$

Le, K. V., 07

Liang, Chenglu, OA

Liu, Yang, OA

Naka, Y., 07

Nakanishi, Yusuke, OA

Nakano, M., 07

O'Donnell, Ryan M., 04

Ohta, M., 07

Rosanov, Nikolay N., 03

Sasaki, T., 07

Shensky, William M., 04

Shi, Jianmin, 04

Suda, T., 07

Terazono, T., 07

Thomas, Jayan, OA

Varma, Sreekanth J., OA

Veretenov, Nikolay A., 03

Wu, Jingjie, OA

Yang, Wei, OA 
Proc. of SPIE Vol. $103601036001-6$

Downloaded From: https://www.spiedigitallibrary.org/conference-proceedings-of-spie on 26 Apr 2023 Terms of Use: https://www.spiedigitallibrary.org/terms-of-use 


\title{
Conference Committee
}

\author{
Symposium Chairs
}

Zakya H. Kafafi, Lehigh University (United States)

Ifor D. W. Samuel, University of St. Andrews (United Kingdom)

Conference Chair

Manfred Eich, Technische Universität Hamburg-Harburg (Germany)

Conference Co-chairs

Jean-Michel Nunzi, Queen's University (Canada)

Jon A. Schuller, University of California, Santa Barbara (United States)

Joy E. Haley, Air Force Research Laboratory (United States)

Conference Program Committee

Dean R. Evans, Air Force Research Laboratory (United States)

Mark G. Kuzyk, Washington State University (United States)

Charles Y. C. Lee, Air Force Office of Scientific Research (United States)

Zouheir Sekkat, University Mohammed V (Morocco)

Matthew Y. Sfeir, Brookhaven National Laboratory (United States)

William M. Shensky III, U.S. Army Research Laboratory (United States)

Jayan Thomas, CREOL, The College of Optics and Photonics,

University of Central Florida (United States)

Naoto Tsutsumi, Kyoto Institute of Technology (Japan)

\section{Session Chairs}

1 Nonlinear Optical Processes and Mechanisms I

Manfred Eich, Technische Universität Hamburg-Harburg (Germany)

2 Nonlinear Optical Processes and Mechanisms II

David J. Hagan, CREOL, The College of Optics and Photonics,

University of Central Florida (United States)

3 Materials, Devices and Applications I

Zouheir Sekkat, Moroccan Foundation for Advanced Science, Innovation and Research (Morocco) 
4 Materials, Devices and Applications II

Toshiyuki Watanabe, Tokyo University of Agriculture and Technology (Japan) 